\title{
Market structure, state ownership and monetary policy transmission through bank lending channel: Evidence from Vietnamese commercial banks
}

\author{
Huu Huan Nguyen • Minh Vu Ngo • Thanh Phuc Nguyen* \\ University of Economics Ho Chi Minh City, Vietnam
}

Received: 2 September 2020

Revised: 8 January 2021

Accepted: 11 January 2021

\begin{abstract}
This paper examines the impact of market structure and state ownership on bank lending as a transmission channel for monetary policies. For controlling the effects of bank heterogeneities and macroeconomic factors on bank lending, dynamic models using two-step difference GMM with panel data collected from 25 Vietnamese commercial banks and the Vietnamese banking sector from 1999 to 2017 are employed. Results indicate that a higher level of concentration in the banking market and state ownership dampen the expected impacts of interbank interest rate on the loan growth in commercial banks, which decreases the effectiveness of monetary policy via the bank lending channel. These results are robust regarding the use of alternative measures of market structure and the inclusion of event time variables in the dynamic model. Based on the findings, monetary policy could be implied using the significant moderating impacts of state-ownership as well as the market structure of the Vietnamese banking sector on the relationship between bank loan supply and interbank interest rate.
\end{abstract}

Keywords: market structure; state-owned equity; monetary policy transmission; Vietnamese commercial banks

JEL Classification Codes: G21, E52, L33, P13

\section{Introduction}

The topic of the monetary policy transmission receives great interest from both scholars and policy-makers due to its essential roles in economic growth (Altunbaş et al. 2002; Bernanke 1993; Bernanke and Gertler 1995; Gambacorta 2005; Kashyap and Stein 1994; Kashyap et al. 1992; Pham 2019). The prioritized channels of transmission could vary across economies based on the level of financial integration and openness, the structure of ownership, macroeconomic factors, regulatory and the structure of financial markets (Allen et al. 2017; Altunbas et al. 2009; Olivero et al. 2011a; Perera et al. 2014). Particularly in Vietnam, where most firms heavily rely

\footnotetext{
*Corresponding author. E-mail: thanhphuc.ueh@gmail.com.

Citation: Nguyen, H. H., Ngo, M. V., and Nguyen, T. P. (2021) Market structure, state ownership and monetary policy transmission through bank lending channel: Evidence from Vietnamese commercial banks, Economics and Business Letters, 10(3), 164-177.
}

DOI: 10.17811/ebl.10.3.2021.164-177 
on bank loans as their primary funding sources, the bank lending channel is genuinely essential. Recently, the ongoing largest-ever nonperforming loan in commercial banks sectors has been one of the most major policy-related changes in bank restructuring, affecting the overall picture of competition and risks in the market (Huynh et al. 2020; Ngo et al. 2019). Moreover, because of the dominant role of state-ownership in bank capital structures in Vietnam, it is urgent to investigate how these issues influence monetary transmission effectiveness.

Regarding banking market structure, previous studies found consistent evidence for its significant moderating roles on the effectiveness of monetary policy transmission (Olivero et al. 2011a; 2011b). Specifically, the weakening of monetary policy transmission via bank lending mechanism is expected when there is higher competition in the banking sector. There are two main channels through that banking market structures could influence monetary policy transmission. First, in a higher competitive environment created by the expansion of larger banks' market share, these larger banks could typically access more sources of funds rather than just the deposits or interbank loans so that they could counteract the monetary policy tightening much easier. Second, an increase in competition could reduce the informational asymmetric across banks on borrowers' financial profile creating lower switching cost for borrowers to move from small banks (who are usually severely affected by the reduction in credit supply) to larger banks (who are better in protecting their money supply) (Olivero et al. 2011a; 2011b). Thus, in this case, at the aggregate level, the impacts of tightening monetary policy on loan demand and supply could be significantly reduced.

Surprisingly, very few studies paid attention to the impacts of ownership structure on the effectiveness of monetary policy transmission. Only recently, some studies found mixed results about the impacts of state ownership level on monetary policy transmission in the banking sector, especially in emerging markets where public banks account for major banking assets (Bashir et al. 2020; Bhaumik et al. 2011). On the one hand, banks with high private ownership are typically more modernized and have much more diverse sources of funds compared to stateowned banks. Therefore, privately-owned banks could employ more alternative funds to smooth their operations than state-owned banks in the event of tightening monetary policy (Bashir et al. 2020). On the other hand, state-owned banks are found to be less responsive to the macroeconomic shocks and charge significantly lower interest rates to firms than privatelyowned banks (Micco and Panizza 2006; Sapienza 2004), which reduces expected market impacts of monetary policy.

In general, this paper focuses on the market structure and the ownership structure in Vietnamese banking sectors to provide empirical evidence of their moderating impacts on the relationships between the interbank interest rate and loan supply of commercial banks over 1999-2017. The two main research questions are proposed:

Research question 1: Does the market structure in the Vietnamese banking sector significantly influence the effectiveness of monetary policy transmission by moderating the relationship between the interbank interest rate and bank loan supply?

Research question 2: Does the state ownership in the Vietnamese banking sector significantly influence the effectiveness of monetary policy transmission by moderating the relationship between the interbank interest rate and bank loan supply?

\section{Data and methodology}

\subsection{Data}

Starting with more than 35 commercial banks in the Vietnamese banking market, we remove banks that is forced into bankruptcy in the period and banks with completely missing data of one of the variables. Then, a set of unbalanced data of 25 operating commercial banks covering the period of 1999-2017 is collected. The data in the financial report such as balance sheets and income statements are retrieved from the Bankscope. Macroeconomic data such as GDP growth 
and inflation index are retrieved from Worldbank. The Interbank rate is retrieved from the State bank of Vietnam. Market structure data is calculated and described in detail below and in Table 1.

\subsection{Methodology}

In accordance with prior studies which used the dynamic model for investigating monetary policy effects (Ehrmann et al. 2003; Fungáčová et al. 2016; Gunji and Yuan 2010), the general form of econometric regressions ${ }^{1}$ are presented as follows.

$$
\begin{aligned}
& \Delta \ln L O A N_{i t}=\alpha * \Delta \ln L O A N_{i t-1}+\beta * \Delta I I R_{t}+\gamma * \text { MARKETPOWER }+\varnothing * \\
& \text { MARKETPOWER } R_{t} I_{I I R_{t}}+\theta * B C_{i t}+\varphi * M C_{i t}+\tau_{i t}+\varepsilon_{i t} \\
& \Delta \ln L O A N_{i t}=\alpha * \Delta \ln L O A N_{i t-1}+\beta * \Delta I I R_{t}+\gamma * S T A T E O W N E R S H I P_{i t}+\emptyset * \\
& \text { STATE OWNERSHIP } i t * I I R_{t}+\theta * B C_{i t}+\varphi * M C_{i t}+\tau_{i t}+\varepsilon_{i t}
\end{aligned}
$$

where the dependent variable, $\triangle \ln L O A N_{i t}$ is the relative change of loan for bank $\mathrm{i}$ at time $\mathrm{t}$. $\Delta I I R_{i t}$ is the change of annual average interbank interest rate from the previous period that reflects the monetary policy of the State Bank of Vietnam for a given bank $\mathrm{i}$ at time $\mathrm{t}$. $B C_{i t}$ represent the banks' characteristics including bank size $\left(S I Z E_{i t}\right)$, capitalization $\left(C A P_{i t}\right)$, liquidity $\left(L I Q_{i t}\right)$, and nonperforming loan index $\left(N P L_{i t}\right) . M C_{i t}$ refers to the variables accounting for macroeconomic factors such as the growth of gross domestic product (GDPG $G_{t}$, the inflation $\left(I N F_{t}\right)$ and volatility index $\left(V I X_{t}\right) \cdot \tau_{i t}$ is bank-specific impact unobserved individually and $\varepsilon_{i t}$ is the error term.

\subsubsection{Market structure proxies}

There are different measures for the market structure, which could be separated into two types. The first proxy is the nonstructural measurement, the Lerner index, used to account for bank conducts based on the condition of demand and supply gained by the position of banks in the market (Berger et al. 2017). In this paper, the Lerner index is employed as a market structure measure of the Vietnamese banking sector as a whole and is computed according to the work of De Guevara et al. (2005) and Demirguc-Kunt and Martínez Pería (2010).

Market competitiveness could be created due to higher concentration, suggesting that banks with a monopoly condition could access more sources of funds and could counteract the expected impacts of tightening monetary policy. Therefore, the second type, HerfindahlHirschman Index (HHI), is employed in the robustness tests to proxy for the market structure from the perspective of market share (Rhoades 1993). Table 1 represents the definitions and calculations of the two market structure proxies and other variables.

\subsection{Econometric specification}

In this research, the two-step difference generalized method of moments (GMM) is used for unbiased estimation of dynamic models where sample data includes a large number of crosssectional observations and a short time span. Apart from the one-step difference GMM (Arellano and Bover 1995; Blundell and Bond 1998), the two-step difference GMM could address the conditions where the independent measurements are not completely exogenous and can be associated with the previous or present time value of residuals. Furthermore, the Hansen statistics are also used to test the instruments' validity and the presence of the identification problem, and values of $\mathrm{AR}(1)$ and $\mathrm{AR}(2)$ are employed to test the presence of the serial correlation problem in dynamic models.

\footnotetext{
${ }^{1}$ Eq. 1 aims to investigate the existence of the market power and the importance of bank lending mechanism while Eq. 2 is employed to test the effectiveness of monetary policy transmission based on the existence of state ownership.
} 
Table 1. Variable descriptions.

\begin{tabular}{|c|c|}
\hline Variables & Description \\
\hline$\Delta \ln L O A N_{i t}$ & $\begin{array}{l}\text { The relative change in loan for bank } i \text { at time } t \text { calculated using the } \\
\text { difference in natural logarithms of loan between the two consecutive years }\end{array}$ \\
\hline$L E R N E R_{t}$ & $\begin{array}{l}\text { The nonstructural index of market structure overtime for the banking } \\
\text { sector in Vietnam calculated by taking the difference in the prices of } \\
\text { output and the marginal costs. The form of this index is as follows the } \\
\text { approach of Demirguc-Kunt and Martínez Pería }(2010) \text {. Lerner index } \\
\text { value ranges from } 0 \text { to } 1 \text {. A lower Lerner index value shows the increase } \\
\text { in competition in the banking market. The Lerner index of Vietnamese } \\
\text { bank market is retrieved from FRED (Federal Reserve Bank of St. Louis) }\end{array}$ \\
\hline$H H I_{t}$ & $\begin{array}{l}\text { The structural index of market concentration overtime for the banking } \\
\text { sector in Vietnam, computed by the total squared market share of all banks } \\
\text { in a loan market. HHI value ranges from } 0 \text { to } 1 \text {. A lower HHI value depicts } \\
\text { the increase in competition in the banking market }\end{array}$ \\
\hline STATE OWNERSHIP $P_{i t}$ & $\begin{array}{l}\text { Dummy variables for state-owned equity for bank } i \text { at time } t \text {, with the } \\
\text { value of } 1 \text { for the bank with the existence of state ownership which is more } \\
\text { than } 50 \% \text {, and } 0 \text { otherwise }\end{array}$ \\
\hline$\Delta I I R_{t}$ & $\begin{array}{l}\text { The } \% \text { change in the annual average of interbank interest rate from the } \\
\text { previous period used as the proxy for the monetary policy of the } \\
\text { Vietnamese state-bank through the banking lending channel at time t }\end{array}$ \\
\hline \multirow{2}{*}{$S I Z E_{i t}$} & $\begin{array}{l}\text { The logarithm form of total assets of bank } \mathrm{i} \text { at time t. This proxy is } \\
\text { normalized with regards to their sample averages: }\end{array}$ \\
\hline & $S I Z E_{i t}=\log (\text { total assets })_{i t}-\frac{1}{N_{t}} \sum_{i} \log (\text { total assets })_{i t}$ \\
\hline \multirow{2}{*}{$C A P_{i t}$} & $\begin{array}{l}\text { The equity divided by the total assets. This proxy is normalized with } \\
\text { regards to their sample averages: } \\
\text { Equity }\end{array}$ \\
\hline & $C_{A} P_{i t}=\frac{1}{\text { Total assets }_{i t}}-\bar{T} \sum_{i} \overline{N_{t}} \sum_{i} \frac{1}{\text { Total assets }_{i t}}$ \\
\hline \multirow[b]{2}{*}{$L I Q_{i t}$} & $\begin{array}{l}\text { The liquid assets divided by the total assets. This proxy is normalized with } \\
\text { regards to their sample averages: }\end{array}$ \\
\hline & $L^{L} Q_{i t}=\frac{{\text { Liquid } \text { assets }_{i t}}_{\text {Total assets }} i t}{\text { Tot }}-\frac{1}{T} \sum_{i} \frac{1}{N_{t}} \sum_{i} \frac{\text { Liquid assets }_{i t}}{\text { Total assets }}$ \\
\hline \multirow{3}{*}{$N P L_{i t}$} & $\begin{array}{l}\text { The ratio of non-performing loans to total loans. This proxy is normalized } \\
\text { with regards to their sample averages: } \\
\text { Nonperforming loan }{ }_{i t}\end{array}$ \\
\hline & $N L P_{i t}=\frac{\text { Total loan }}{i t}$ \\
\hline & $-\frac{1}{T} \sum_{i} \frac{1}{N_{t}} \sum_{i} \frac{\text { Nonperforming } \operatorname{loan}_{i t}}{\text { Total loan }}$ \\
\hline$G D P G_{t}$ & $\begin{array}{l}\text { The annual growth of the gross domestic product of Vietnam retrived from } \\
\text { Worldbank }\end{array}$ \\
\hline$I N F_{t}$ & $\begin{array}{l}\text { The annual inflation calculated through the consumer price index of } \\
\text { Vietnam retrived from Worldbank }\end{array}$ \\
\hline$V I X_{t}$ & $\begin{array}{l}\text { Annual average Volatility index retrived from FRED, Federal Reserve } \\
\text { Bank of St. Louis }\end{array}$ \\
\hline & Dummy variable for the event before and after Vietnam officially joins \\
\hline$W T O_{t}$ & $\begin{array}{l}\text { World Trade Organizations, with the value of } 1 \text { after the year of 2007, and } \\
0 \text { otherwise }\end{array}$ \\
\hline CRISIS $_{t}$ & $\begin{array}{l}\text { Dummy variable for the global financial crisis event happened in } 2007 \\
\text { and } 2008 \text {, with the value of } 1 \text { for the year of } 2007 \text { and } 2008 \text {, and } 0 \\
\text { otherwise }\end{array}$ \\
\hline
\end{tabular}


Table 2. Descriptive statistics of variables.

\begin{tabular}{lccrrr}
\hline Variable & Obs & Mean & SD & Min & Max \\
\hline$\triangle \ln L O A N$ & 250 & 0.111 & 0.779 & -6.14 & 3.93 \\
LERNER & 400 & 0.228 & 0.037 & 0.157 & 0.309 \\
HHI & 475 & 0.732 & 0.152 & 0.545 & 0.971 \\
$\triangle I I R$ & 418 & 0.383 & 0.95 & -0.741 & 8.992 \\
SIZE & 275 & 0.099 & 0.722 & -3.021 & 1.784 \\
LIQ & 242 & 0.299 & 0.895 & -0.046 & 13.966 \\
CAP & 264 & 0.083 & 0.044 & 0.005 & 0.449 \\
NPL & 261 & 5.248 & 11.995 & 0.000 & 81.880 \\
GDPG & 475 & 6.328 & 0.754 & 4.774 & 7.547 \\
$I N F$ & 475 & 6.749 & 5.767 & -1.580 & 23.060 \\
VIX & 474 & 19.936 & 7.002 & 11.040 & 40.000 \\
\hline \hline
\end{tabular}

Notes: Table 2 shows the descriptive statistics of variables. Variable definitions are reported in Table 1. The observation (Obs), mean, standard deviation (SD), minimum (Min) and maximum (Max) are illustrated, respectively for each variable. Sources: Bankscope and FRED.

Table 3: Correlation between variables.

\begin{tabular}{|c|c|c|c|c|c|c|c|c|c|c|c|c|}
\hline & 1 & 2 & 3 & 4 & 5 & 6 & 7 & 8 & 9 & 10 & 11 \\
\hline \multicolumn{2}{|c|}{$\begin{array}{cc}\text { Variables } \\
1 \quad \text { SIZE }\end{array}$} & 1.000 & & & & & & & & & & \\
\hline 2 & $L I Q$ & -0.257 & 1.000 & & & & & & & & & \\
\hline 3 & $C A P$ & -0.158 & 0.200 & 1.000 & & & & & & & & \\
\hline 4 & $\triangle \ln L O A N$ & -0.101 & 0.065 & 0.123 & 1.000 & & & & & & & \\
\hline 5 & $G D P G$ & -0.444 & 0.214 & -0.185 & 0.127 & 1.000 & & & & & & \\
\hline 6 & $I N F$ & 0.157 & -0.099 & 0.115 & 0.084 & -0.058 & 1.000 & & & & & \\
\hline 7 & $\Delta I I R$ & -0.228 & 0.167 & -0.005 & -0.394 & 0.340 & -0.106 & 1.000 & & & & \\
\hline 8 & $N P L$ & -0.004 & 0.201 & 0.082 & -0.030 & -0.092 & -0.035 & 0.189 & 1.000 & & & \\
\hline 9 & VIX & -0.166 & 0.001 & 0.193 & 0.014 & -0.142 & 0.688 & 0.122 & -0.060 & 1.000 & & \\
\hline 10 & $H H I$ & -0.679 & 0.256 & -0.207 & 0.063 & 0.459 & -0.347 & 0.095 & -0.075 & 0.068 & 1.000 & \\
\hline 11 & LERNER & -0.385 & 0.207 & -0.060 & 0.238 & 0.869 & -0.050 & 0.088 & -0.118 & -0.084 & 0.368 & 1.000 \\
\hline
\end{tabular}

Notes: Table 3 shows the correlation matrix across variables of interest. Variable definitions are reported in Table 1. Sources: Bankscope and FRED.

\section{Empirical results and discussion}

\subsection{Descriptive statistics}

The descriptive statistics of variables are reported in Table 2. The average value of marker power shows the competition and concentration of the Vietnamese commercial banking system. The average Lerner index is 0.228 indicating the Vietnamese banking market is highly competitive. The average annual changes in bank loans are approximately 0.111 . The average annual change in IIR over time is 0.383 . Table 3 presents the correlation matrix between variables.

\subsection{Market structure, interbank rate and the monetary policy transmission via bank lending channel}

Answering Research question 1, an interaction term of the market structure and interbank rate $(L E R N E R * I I R)$ is included in the two-step difference GMM dynamic models of changes in bank loans reported in Table 4. As presented, IIR as the monetary policy instrument shows a significant negative relationship with bank loan changes, which is consistent with the expected 
Table 4: Estimation for loan growth: the interaction effects of market structure (Lerner index - LERNER) and interbank interest rate.

\begin{tabular}{|c|c|c|}
\hline Variables & $\begin{array}{r}\ln L O A N \\
(1)\end{array}$ & $\begin{array}{r}\operatorname{InLOAN} \\
\text { (2) }\end{array}$ \\
\hline$\triangle \ln L O A N_{-1}$ & $\begin{array}{c}-0.250^{* * * *} \\
(-9.416)\end{array}$ & $\begin{array}{c}-0.228^{* * * *} \\
(-3.502)\end{array}$ \\
\hline$I I R$ & $\begin{array}{l}-0.514^{* * * *} \\
(-10.670)\end{array}$ & $\begin{array}{r}-1.518^{* * * *} \\
(-3.198)\end{array}$ \\
\hline LERNER & $\begin{array}{r}0.240^{* * * *} \\
(5.155)\end{array}$ & $\begin{array}{l}0.174^{* * *} \\
(2.522)\end{array}$ \\
\hline LERNER * IIR & & $\begin{array}{l}1.108^{* * *} \\
(2.670)\end{array}$ \\
\hline SIZE & $\begin{array}{c}-0.100^{* * * *} \\
(-3.568)\end{array}$ & $\begin{array}{r}-0.046 \\
(-1.258)\end{array}$ \\
\hline$L I Q$ & $\begin{array}{c}-0.083^{*} \\
(-1.774)\end{array}$ & $\begin{array}{r}-0.016 \\
(-0.373)\end{array}$ \\
\hline CAP & $\begin{array}{r}0.047 \\
(1.175)\end{array}$ & $\begin{array}{r}0.036 \\
(1.187)\end{array}$ \\
\hline$N P L$ & $\begin{array}{l}0.133^{* * *} \\
(2.687)\end{array}$ & $\begin{array}{r}0.053 \\
(1.291)\end{array}$ \\
\hline$G D P G$ & $\begin{array}{r}0.094 \\
(1.535)\end{array}$ & $\begin{array}{r}0.113 \\
(1.306)\end{array}$ \\
\hline INF & $\begin{array}{c}0.187^{* * * *} \\
(3.908)\end{array}$ & $\begin{array}{c}0.128^{*} \\
(1.755)\end{array}$ \\
\hline$V I X$ & $\begin{array}{r}-0.010 \\
(-0.242)\end{array}$ & $\begin{array}{r}0.052 \\
(1.359)\end{array}$ \\
\hline$N$ & 149 & 149 \\
\hline Bank & 25 & 25 \\
\hline Year & $1999-2017$ & 1999-2017 \\
\hline Groups & 24 & 24 \\
\hline Instruments & 25 & 38 \\
\hline $\operatorname{AR}(1)$ & 0.113 & 0.152 \\
\hline $\operatorname{AR}(2)$ & 0.332 & 0.102 \\
\hline Hansen test & 0.713 & 0.611 \\
\hline
\end{tabular}

Notes: The model diagnostics show the insignificant value of AR(1) and $\mathrm{AR}(2)$, indicating no first and second-order serial correlation of the error term. The problem of over-identification restriction does not exist due to the failure to reject the Hansen test's null hypothesis. *, **, and *** show statistical significance for $\mathrm{p}$-value $<0.1$, p-value $<0.05$, and $\mathrm{p}$-value $<0.01$, respectively. $\mathrm{t}$-value in parentheses. Variable definitions are reported in Table 1.

theory on the monetary policy implication. The interaction term, LERNER $* I I R$ is statistically positive at the $1 \%$ level of significance, suggesting that with a lower level of competition in the banking market (higher level of Lerner index), the expected negative impact of interbank rate is significantly reduced. This finding supports the moderating effects of market structure in the use of bank lending mechanism for transmitting monetary policy by reducing the effectiveness of IIR for transmitting the monetary policy via bank loan supply. These results are in line with the research of Bashir et al. (2020).

\subsection{State ownership, interbank rate and the monetary policy transmission via bank lending channel}

Answering Research question 2, an interaction term of the state ownership and interbank rate (STATE OWNERSHIP *IIR) is included in the two-step difference GMM dynamic models of 
Table 5. Estimation for loan growth: the interaction effects of state ownership and interbank interest rate.

\begin{tabular}{|c|c|c|}
\hline Variables & $\begin{array}{r}\ln L O A N \\
(1) \\
\end{array}$ & $\begin{array}{r}\operatorname{InLOAN} \\
(2) \\
\end{array}$ \\
\hline$\triangle \ln L O A N_{-1}$ & $\begin{array}{c}0.119^{* * * *} \\
(4.270)\end{array}$ & $\begin{array}{c}0.137^{* * * *} \\
(5.039)\end{array}$ \\
\hline IIR & $\begin{array}{c}-0.422^{* * * *} \\
(-3.603)\end{array}$ & $\begin{array}{c}-0.594^{* * * *} \\
(-9.686)\end{array}$ \\
\hline STATE OWNERSHIP & $\begin{array}{r}0.635 \\
(1.674)\end{array}$ & $\begin{array}{r}-0.223 \\
(-1.388)\end{array}$ \\
\hline STATE OWNERSHIP * IIR & & $\begin{array}{r}0.180^{* * * *} \\
(5.098)\end{array}$ \\
\hline SIZE & $\begin{array}{r}0.057 \\
(0.742)\end{array}$ & $\begin{array}{r}-0.078^{*} \\
(-1.773)\end{array}$ \\
\hline$L I Q$ & $\begin{array}{c}0.013^{* * * *} \\
(3.610)\end{array}$ & $\begin{array}{c}0.026^{* * * *} \\
(3.747)\end{array}$ \\
\hline$C A P$ & $\begin{array}{r}0.146 \\
(1.275)\end{array}$ & $\begin{array}{l}-0.076^{* * *} \\
(-2.167)\end{array}$ \\
\hline$N P L$ & $\begin{array}{c}0.590^{* * * *} \\
(2.933)\end{array}$ & $\begin{array}{c}0.259^{* * * *} \\
(8.297)\end{array}$ \\
\hline$G D P G$ & $\begin{array}{l}0.105^{* *} \\
(2.527)\end{array}$ & $\begin{array}{c}0.090^{* * * *} \\
(8.721)\end{array}$ \\
\hline INF & $\begin{array}{r}0.041 \\
(1.011)\end{array}$ & $\begin{array}{c}0.096^{* * *} \\
(2.840)\end{array}$ \\
\hline VIX & $\begin{array}{c}-0.128^{* * * *} \\
(-3.504)\end{array}$ & $\begin{array}{r}-0.174^{* * * *} \\
(-5.472)\end{array}$ \\
\hline$N$ & 188 & 188 \\
\hline Bank & 25 & 25 \\
\hline Year & $1999-2017$ & $1999-2017$ \\
\hline Groups & 25 & 25 \\
\hline Instruments & 24 & 27 \\
\hline $\operatorname{AR}(1)$ & 0.227 & 0.267 \\
\hline $\operatorname{AR}(2)$ & 0.068 & 0.062 \\
\hline Hansen test & 0.631 & 0.602 \\
\hline
\end{tabular}

Notes: The model diagnostics show the insignificant value of $\operatorname{AR}(1)$ and $\operatorname{AR}(2)$, indicating no first and second-order serial correlation of the error term. The problem of over-identification restriction does not exist due to the failure to reject the Hansen test's null hypothesis. *, **, and $* * *$ show statistical significance for $\mathrm{p}$-value $<0.1$, p-value $<$ 0.05 , and $\mathrm{p}$-value $<0.01$, respectively. $\mathrm{t}$-value in parentheses. Variable definitions are reported in Table 1.

changes in bank loans reported in Table 5. As reported in Table 5, the IIR's role as a monetary policy instrument and its significant negative impacts on bank loans remained. State ownership alone does not have significant impacts on bank loan supply ( $\mathrm{p}$-value $>>0.05$ ). However, its interaction with IIR via the interaction terms is statistically significant (p-value $<0.01$ ). More importantly, the interactive term poses a positive impact on change in bank loans, suggesting that a higher level of state ownership in banks could weaken the expected negative impacts of IIR as a monetary policy tool on bank loan supply. This moderating effect of state ownership is similar to the work of Ferri et al. (2014), suggesting the dampened effect of ownership on the effectiveness of policy transmission via bank lending mechanism.

\subsection{Robustness tests with alternative measures, estimations and control variables}

The alternative measure of market structure, $H H I$, is employed that reflects the market concentration or market structure. In Table 6, the findings remain consistent with Table 5, 
Table 6. Robustness test of estimation for loan growth: the interaction effects of market structure (Hirschman-Herfindahl index - HHI) and interbank interest rate.

\begin{tabular}{|c|c|c|}
\hline Variables & $\begin{array}{r}\triangle \ln L O A N \\
(1)\end{array}$ & $\begin{array}{r}\ln L O A N \\
\text { (2) }\end{array}$ \\
\hline$\triangle \ln L O A N_{-1}$ & $\begin{array}{c}-0.187^{* * * *} \\
(-7.552)\end{array}$ & $\begin{array}{r}-0.089^{* * * *} \\
(-6.446)\end{array}$ \\
\hline$I I R$ & $\begin{array}{c}-0.695^{* * *} \\
(-7.329)\end{array}$ & $\begin{array}{r}-2.524^{* * * * *} \\
(-8.302)\end{array}$ \\
\hline$H H I$ & $\begin{array}{c}0.438^{* * * *} \\
(11.573)\end{array}$ & $\begin{array}{r}0.154^{* * * * *} \\
(5.752)\end{array}$ \\
\hline$H H I * I I R$ & & $\begin{array}{r}1.684^{* * * *} \\
(5.865)\end{array}$ \\
\hline SIZE & $\begin{array}{c}0.107^{* * * *} \\
(4.168)\end{array}$ & $\begin{array}{c}0.077^{*} \\
(1.810)\end{array}$ \\
\hline$L I Q$ & $\begin{array}{c}-0.020^{* * * *} \\
(-5.431)\end{array}$ & $\begin{array}{r}-0.007 \\
(-0.731)\end{array}$ \\
\hline$C A P$ & $\begin{array}{l}0.115^{* *} \\
(2.572)\end{array}$ & $\begin{array}{c}0.191^{* * * * *} \\
(6.326)\end{array}$ \\
\hline$N P L$ & $\begin{array}{c}0.323^{* * *} \\
(6.959)\end{array}$ & $\begin{array}{c}0.440^{* * * * * *} \\
(16.685)\end{array}$ \\
\hline$G D P G$ & $\begin{array}{c}0.120^{* * * *} \\
(13.044)\end{array}$ & $\begin{array}{c}0.344^{* * * * * *} \\
(19.014)\end{array}$ \\
\hline$I N F$ & $\begin{array}{c}0.331^{* * * *} \\
(6.978)\end{array}$ & $\begin{array}{c}0.230^{* * * *} \\
(4.279)\end{array}$ \\
\hline$V I X$ & $\begin{array}{c}-0.255^{* * *} \\
(-9.534)\end{array}$ & $\begin{array}{l}-0.106^{* * *} \\
(-2.169)\end{array}$ \\
\hline$N$ & 188 & 188 \\
\hline Bank & 25 & 25 \\
\hline Year & 1999-2017 & 1999-2017 \\
\hline Groups & 25 & 25 \\
\hline Instruments & 27 & 27 \\
\hline $\operatorname{AR}(1)$ & 0.165 & 0.129 \\
\hline $\operatorname{AR}(2)$ & 0.107 & 0.169 \\
\hline Hansen test & 0.301 & 0.415 \\
\hline
\end{tabular}

Notes: The model diagnostics show the insignificant value of $\mathrm{AR}(1)$ and $\mathrm{AR}(2)$, indicating no first and second-order serial correlation of the error term. The problem of over-identification restriction does not exist due to the failure to reject the Hansen test's null hypothesis. *,**, and *** show statistical significance for p-value $<0.1$, p-value $<0.05$, and p-value $<0.01$, respectively. t-value in parentheses. Variable definitions are reported in Table 1.

representing the significantly positive coefficient of the interaction term between $H H I$ and interbank interest rate $(H H I * I I R)$ at $1 \%$ level. This finding affirms the moderating effects of market structure on the use of $I I R$ as the monetary policy instrument. So, there is a significant reduction in policy transmitting effectiveness if the level of competition in the banking market is low.

Table 7 reports the significant at 5\% level and positive impacts of the interaction term of the state ownership and interbank rate (STATE OWNERSHIP *IIR) when including market structure (LERNER and $H H I)$ as control variables. The findings are persistent with the discussion aforementioned in Table 5, suggesting that even when accounting for market structure variables, a higher level of state ownership in banks could weaken the expected negative impacts of $I I R$ as a monetary policy tool on bank loan supply, thus, reducing the transmitting effects of monetary policy via bank loan supply on the economy. 
Table 7. Robustness test of estimation for loan growth: the interaction effects of state ownership and interbank interest rate controlling for market structure index

\begin{tabular}{|c|c|c|}
\hline Variables & $\begin{array}{r}\Delta \operatorname{In} L O A N \\
(1)\end{array}$ & $\begin{array}{r}\triangle \operatorname{In} L O A N \\
(2)\end{array}$ \\
\hline$\triangle \ln L O A N_{-1}$ & $\begin{array}{c}0.188^{* * *} \\
(6.141)\end{array}$ & $\begin{array}{r}-0.016^{\text {**** }} \\
(-4.525)\end{array}$ \\
\hline$I I R$ & $\begin{array}{c}-0.572^{* * *} \\
(-6.213)\end{array}$ & $\begin{array}{r}-0.571^{* * * *} \\
(-8.080)\end{array}$ \\
\hline STATE OWNERSHIP * IIR & $\begin{array}{l}0.341^{* *} \\
(2.779)\end{array}$ & $\begin{array}{l}0.402^{* *} \\
(2.352)\end{array}$ \\
\hline LERNER & $\begin{array}{l}0.109^{* * *} \\
(2.213)\end{array}$ & \\
\hline$H H I$ & & $\begin{array}{r}0.288^{* * * *} \\
(3.343)\end{array}$ \\
\hline SIZE & $\begin{array}{r}-0.021 \\
(-0.644)\end{array}$ & $\begin{array}{r}-0.041 \\
(-1.295)\end{array}$ \\
\hline$L I Q$ & $\begin{array}{l}0.022^{* * *} \\
(2.532)\end{array}$ & $\begin{array}{r}-0.063 \\
(-1.686)\end{array}$ \\
\hline CAP & $\begin{array}{r}0.067 \\
(1.327)\end{array}$ & $\begin{array}{r}0.019 \\
(0.462)\end{array}$ \\
\hline$N P L$ & $\begin{array}{r}0.231^{* * * *} \\
(6.012)\end{array}$ & $\begin{array}{l}0.096^{* *} \\
(2.765)\end{array}$ \\
\hline$G D P G$ & $\begin{array}{l}-0.045^{* * *} \\
(-2.401)\end{array}$ & $\begin{array}{r}-0.117 \\
(-1.226)\end{array}$ \\
\hline$I N F$ & $\begin{array}{c}0.115^{*} \\
(1.955)\end{array}$ & $\begin{array}{c}0.127^{*} \\
(1.978)\end{array}$ \\
\hline$V I X$ & $\begin{array}{r}-0.191^{* * * *} \\
(-3.881)\end{array}$ & $\begin{array}{l}-0.102^{* *} \\
(-2.488)\end{array}$ \\
\hline$N$ & 149 & 188 \\
\hline Bank & 25 & 25 \\
\hline Year & 1999-2017 & $1999-2017$ \\
\hline Groups & 25 & 25 \\
\hline Instruments & 27 & 27 \\
\hline $\mathrm{AR}(1)$ & 0.594 & 0.244 \\
\hline $\operatorname{AR}(2)$ & 0.725 & 0.082 \\
\hline Hansen test & 0.574 & 0.517 \\
\hline
\end{tabular}

Notes: The model diagnostics show the insignificant value of $\mathrm{AR}(1)$ and $\mathrm{AR}(2)$, indicating no first and second-order serial correlation of the error term. The problem of over-identification restriction does not exist due to the failure to reject the Hansen test's null hypothesis. *, **, and $* * *$ show statistical significance for $\mathrm{p}$-value $<0.1$, p-value $<0.05$, and $\mathrm{p}$-value $<0.01$, respectively. t-value in parentheses. Variable definitions are reported in Table 1.

The WTO joining in 2007 and the financial crisis brought dramatic changes in the market structure in Vietnam (De Waal et al. 2009; Vo and Nguyen 2018). Thus, accounting for these major recent changes in the financial sector in Vietnam, two event-time control variables are included in the model (WTO and CRISIS). The results in Table 8 again affirm the aforementioned moderating effects of market structure and state ownership even when controlling for major shifts in the market.

Regarding the concern of relative small panel data used in this study, we also confirm the main results' robustness using fixed-effect model estimators. The results in Table 9 again show the significant moderating effects of both market structure and state ownership on the effectiveness of monetary policy transmission. 
Table 8. Robustness test of estimation for loan growth: the moderating effects of market structure (LERNER index) and state ownership controlling for event time variables (WTO and CRISIS).

\begin{tabular}{|c|c|c|c|c|}
\hline Variables & $\begin{array}{r}\triangle \operatorname{InLOAN} \\
(1) \\
\end{array}$ & $\begin{array}{r}\operatorname{SnLOAN} \\
(2) \\
\end{array}$ & $\begin{array}{r}\operatorname{In} L O A N \\
(3) \\
\end{array}$ & $\begin{array}{r}\operatorname{Sn} L O A N \\
(4) \\
\end{array}$ \\
\hline$\triangle \ln L O A N_{-1}$ & $\begin{array}{r}-0.342^{* * *} \\
(-5.903)\end{array}$ & $\begin{array}{r}-0.614^{* * * *} \\
(-5.311)\end{array}$ & $\begin{array}{r}-0.088 \\
(0.066)\end{array}$ & $\begin{array}{r}-0.075 \\
(0.064)\end{array}$ \\
\hline IIR & $\begin{array}{r}-2.113^{* * *} \\
(-5.448)\end{array}$ & $\begin{array}{r}-6.968^{* * *} \\
(-4.347)\end{array}$ & $\begin{array}{r}-0.803^{* * * *} \\
(0.152)\end{array}$ & $\begin{array}{r}-0.669^{* * * *} \\
(0.113)\end{array}$ \\
\hline LERNER & $\begin{array}{c}0.980^{* * * *} \\
(10.004)\end{array}$ & $\begin{array}{r}0.963^{* * * *} \\
(5.619)\end{array}$ & & \\
\hline LERNER * IIR & $\begin{array}{r}2.181^{* * * * *} \\
(6.238)\end{array}$ & $\begin{array}{r}6.136^{* * * *} \\
(4.335)\end{array}$ & & \\
\hline STATE OWNERSHIP & & & $\begin{array}{r}-0.086 \\
(0.075)\end{array}$ & $\begin{array}{c}-0.118 \\
(0.080)\end{array}$ \\
\hline STATE OWNERSHIP * IIR & & & $\begin{array}{l}1.236^{* *} \\
(0.476)\end{array}$ & $\begin{array}{l}1.180^{* *} \\
(0.480)\end{array}$ \\
\hline WTO & $\begin{array}{r}-0.487^{* * * *} \\
(-5.035)\end{array}$ & & $\begin{array}{r}-0.558^{* * *} \\
(0.223)\end{array}$ & \\
\hline CRISIS & & $\begin{array}{r}-0.930^{* * *} \\
(-4.328)\end{array}$ & & $\begin{array}{r}-0.463^{* * *} \\
(0.162)\end{array}$ \\
\hline SIZE & $\begin{array}{r}0.106 \\
(1.362)\end{array}$ & $\begin{array}{r}-0.267^{* * * *} \\
(-4.141)\end{array}$ & $\begin{array}{r}0.033 \\
(0.046)\end{array}$ & $\begin{array}{r}0.190^{*} \\
(0.101)\end{array}$ \\
\hline$L I Q$ & $\begin{array}{l}-0.142^{* *} \\
(-2.346)\end{array}$ & $\begin{array}{r}-0.082 \\
(-1.619)\end{array}$ & $\begin{array}{r}-0.326 \\
(0.299)\end{array}$ & $\begin{array}{r}-0.497 \\
(0.341)\end{array}$ \\
\hline CAP & $\begin{array}{r}0.102 \\
(1.077)\end{array}$ & $\begin{array}{r}0.044 \\
(0.715)\end{array}$ & $\begin{array}{r}2.048 \\
(2.042)\end{array}$ & $\begin{array}{r}2.743 \\
(2.752)\end{array}$ \\
\hline$N P L$ & $\begin{array}{c}0.109^{*} \\
(1.972)\end{array}$ & $\begin{array}{r}0.221^{* * * *} \\
(3.876)\end{array}$ & $\begin{array}{l}0.013^{* *} \\
(0.005)\end{array}$ & $\begin{array}{l}0.012^{* *} \\
(0.005)\end{array}$ \\
\hline$G D P G$ & $\begin{array}{l}-0.863^{* * * *} \\
(-11.011)\end{array}$ & $\begin{array}{r}-0.598^{* * *} \\
(-3.257)\end{array}$ & $\begin{array}{r}0.131 \\
(0.169)\end{array}$ & $\begin{array}{l}-0.052 \\
(0.172)\end{array}$ \\
\hline$I N F$ & $\begin{array}{r}0.463^{* * * *} \\
(3.999)\end{array}$ & $\begin{array}{r}0.488^{* * * *} \\
(3.974)\end{array}$ & $\begin{array}{r}0.001 \\
(0.010)\end{array}$ & $\begin{array}{r}0.007 \\
(0.012)\end{array}$ \\
\hline VIX & $\begin{array}{c}-0.123^{*} \\
(-1.946)\end{array}$ & $\begin{array}{r}0.737^{* * * *} \\
(3.696)\end{array}$ & $\begin{array}{l}0.025^{* *} \\
(0.011)\end{array}$ & $\begin{array}{r}0.008 \\
(0.008)\end{array}$ \\
\hline$N$ & 149 & 149 & 149 & 149 \\
\hline Bank & 25 & 25 & 25 & 25 \\
\hline Year & 1999-2017 & 1999-2017 & 1999-2017 & 1999-2017 \\
\hline Groups & 24 & 24 & 24 & 24 \\
\hline Instruments & 24 & 24 & 24 & 24 \\
\hline $\operatorname{AR}(1)$ & 0.053 & 0.019 & 0.278 & 0.191 \\
\hline $\operatorname{AR}(2)$ & 0.165 & 0.080 & 0.734 & 0.198 \\
\hline Hansen test & 0.480 & 0.505 & 0.548 & 0.536 \\
\hline
\end{tabular}

Notes: The model diagnostics show the insignificant value of $\mathrm{AR}(2)$, indicating no second-order serial correlation of the error term. The problem of over-identification restriction does not exist due to the failure to reject the Hansen test's null hypothesis. *, **, and *** show statistical significance for p-value $<0.1$, p-value $<0.05$, and pvalue $<0.01$, respectively. $t$-value in parentheses. Variable definitions are reported in Table 1. 
Table 9. Robustness test of estimation for loan growth: the interaction effects of market structure and state ownership and interbank interest rate using the fixed effect model.

\begin{tabular}{|c|c|c|c|}
\hline Variables & $\begin{array}{r}\triangle \ln L O A N \\
(1)\end{array}$ & $\begin{array}{r}\triangle \operatorname{InLOAN} \\
\text { (2) }\end{array}$ & $\begin{array}{r}\operatorname{InLOAN} \\
\text { (3) }\end{array}$ \\
\hline$\triangle \ln L O A N_{-1}$ & $\begin{array}{r}-0.384^{* * *} \\
(0.122)\end{array}$ & $\begin{array}{r}0.007 \\
(0.087)\end{array}$ & $\begin{array}{c}-0.266^{* *} \\
(0.113)\end{array}$ \\
\hline IIR & $\begin{array}{c}-3.590^{* *} \\
(1.583)\end{array}$ & $\begin{array}{r}-1.952^{* * *} \\
(0.488)\end{array}$ & $\begin{array}{r}-0.498^{* * *} \\
(0.106)\end{array}$ \\
\hline LERNER & $\begin{array}{r}4.188 \\
(4.400)\end{array}$ & $(-4.347)$ & \\
\hline LERNER * IIR & $\begin{array}{l}15.018^{*} \\
(7.629)\end{array}$ & & \\
\hline$H H I$ & & $\begin{array}{r}0.123 \\
(0.791)\end{array}$ & \\
\hline$H H I * I I R$ & & $\begin{array}{c}2.577^{* * *} \\
(0.691)\end{array}$ & \\
\hline STATE OWNERSHIP * IIR & & & $\begin{array}{l}0.425^{* *} \\
(0.203)\end{array}$ \\
\hline SIZE & $\begin{array}{l}-0.265^{*} \\
(0.135)\end{array}$ & $\begin{array}{r}-0.061 \\
(0.110)\end{array}$ & $\begin{array}{r}-0.197 \\
(0.128)\end{array}$ \\
\hline$L I Q$ & $\begin{array}{r}-0.859 \\
(0.522)\end{array}$ & $\begin{array}{r}-0.038 \\
(0.045)\end{array}$ & $\begin{array}{l}-1.016^{*} \\
(0.521)\end{array}$ \\
\hline CAP & $\begin{array}{r}2.495 \\
(2.368)\end{array}$ & $\begin{array}{r}2.945 \\
(2.005)\end{array}$ & $\begin{array}{r}3.172 \\
(2.356)\end{array}$ \\
\hline$N P L$ & $\begin{array}{r}-0.003 \\
(0.022)\end{array}$ & $\begin{array}{r}-0.018 \\
(0.023)\end{array}$ & $\begin{array}{r}-0.013 \\
(0.022)\end{array}$ \\
\hline$G D P G$ & $\begin{array}{r}-0.080 \\
(0.247)\end{array}$ & $\begin{array}{r}0.109 \\
(0.107)\end{array}$ & $\begin{array}{r}-0.095 \\
(0.247)\end{array}$ \\
\hline$I N F$ & $\begin{array}{c}0.034^{*} \\
(0.018)\end{array}$ & $\begin{array}{r}0.040^{* * * *} \\
(0.015)\end{array}$ & $\begin{array}{c}0.030^{*} \\
(0.017)\end{array}$ \\
\hline VIX & $\begin{array}{r}-0.009 \\
(0.014)\end{array}$ & $\begin{array}{c}-0.024^{* *} \\
(0.012)\end{array}$ & $\begin{array}{r}-0.013 \\
(0.014)\end{array}$ \\
\hline$N$ & 149 & 188 & 149 \\
\hline Adj. $R^{2}$ & 0.144 & 0.020 & 0.147 \\
\hline$B I C$ & 251.499 & 354.530 & 250.871 \\
\hline RSS & 31.531 & 51.942 & 31.399 \\
\hline
\end{tabular}

Notes: Table 9 reports the results of robustness regression using fixed-effect model to account for the concern of relative small panel data. *,**, and *** show statistical significance for pvalue $<0.1, \mathrm{p}$-value $<0.05$, and $\mathrm{p}$-value $<0.01$, respectively. $\mathrm{t}$-value in parentheses. Variable definitions are reported in Table 1.

\section{Conclusion}

Market structure and state ownership are considered as essential factors in this paper for examining the transmitting effectiveness of monetary policy using the interbank rate as an instrument. The results show that the transmitting effect of monetary policy via bank lending mechanism is weakened when the market concentration in the banking sector is higher or the state ownership in commercial banks is high, controlling for bank heterogeneity and macroeconomic factors. 
This research contributes to the area in several ways. Firstly, the prior literature employed aggregate data to examine the monetary policy transmitting effects via bank lending mechanism (Bemanke and James 1991; Bernanke 1990; Hoshi et al. 1993; Kashyap et al. 1992; Oliner and Rudebusch 1993). This paper extends prior research by controlling the effects of the bankspecific characteristic such as ownership structure.

Secondly, banking market structure and state ownership as moderators to the relationship between the interbank rate and loan supply in the context of an ongoing reconstructing banking sector like Vietnam are underexplored. In the case of the Vietnamese banking market, it seems that higher market competition fosters the transmitting effects of monetary policy via bank loan supply. This finding is consistent with the recent work of (Bashir et al. 2020) in the Chinese banking sectors. They found similar findings with this paper that "higher market power and increased concentration tends to make the bank lending channel of monetary policy transmission less effective" (Bashir et al. 2020). The mixed results on this issue could be an exciting and urgent direction for future research to investigate using different contexts and methods given the essence of monetary policy to the economy.

Regarding policy implication, the State Bank of Vietnam has been navigating in the right direction considering the trend of lower market consolidation and lower state ownership in the banking system. The findings in this paper could voice solid support for the current governments' effort to reconstruct the Vietnamese commercial banking system.

\section{Acknowledgements}

We are grateful to Toan Luu Duc Huynh (Guest Editor) and three anonymous reviewers of the journal for their valuable comments to greatly enhance the quality of this research. We also thank Dinh Thanh Su (Session Chair), and conference and seminar participants at the SOBC2020 Conference for helpful suggestions. We appreciate Ngoc Tho Tran, the supervisor of Ph.D. candidate Thanh Phuc Nguyen, for his useful guidance and encouragement. This research is funded by the University of Economics Ho Chi Minh City (Vietnam). This research is also a part of the thesis composed by Thanh Phuc Nguyen. The authors hold responsibility for any remaining errors.

\section{References}

Allen, F., Jackowicz, K., Kowalewski, O. and Kozłowski, Ł. (2017) Bank lending, crises, and changing ownership structure in Central and Eastern European countries, Journal of Corporate Finance, 42, 494-515.

Altunbaş, Y., Fazylov, O. and Molyneux, P. (2002) Evidence on the bank lending channel in Europe, Journal of Banking \& Finance, 26(11), 2093-110.

Altunbas, Y., Gambacorta, L. and Marques-Ibanez, D. (2009) Securitisation and the bank lending channel, European Economic Review, 53(8), 996-1009.

Arellano, M. and Bover, O. (1995) Another look at the instrumental variable estimation of errorcomponents models, Journal of Econometrics, 68(1), 29-51.

Bashir, U., Yugang, Y. and Hussain, M. (2020) Role of bank heterogeneity and market structure in transmitting monetary policy via bank lending channel: empirical evidence from Chinese banking sector, Post-Communist Economies, 1-24.

Bemanke, B. and James, H. (1991) The gold standard, deflation, and financial crisis in the Great Depression: An international comparison, Financial Markets and Financial Crises, University of Chicago Press, 33-68.

Berger, A.N., Klapper, L.F. and Turk-Ariss, R. (2017) Bank competition and financial stability, Handbook of Competition in Banking and Finance, Edward Elgar Publishing. 
Bernanke, B. (1990) The federal funds rate and the channels of monetary transnission, 08982937, National Bureau of Economic Research.

Bernanke, B.S. (1993) Credit in the Macroeconomy, Quarterly Review-Federal Reserve Bank of New York, 18, 50-70.

Bernanke, B.S. and Gertler, M. (1995) Inside the black box: the credit channel of monetary policy transmission, Journal of Economic Perspectives, 9(4), 27-48.

Bhaumik, S.K., Dang, V. and Kutan, A.M. (2011) Implications of bank ownership for the credit channel of monetary policy transmission: Evidence from India, Journal of Banking \& Finance, 35(9), 2418-28.

Blundell, R. and Bond, S. (1998) Initial conditions and moment restrictions in dynamic panel data models, Journal of Econometrics, 87(1), 115-43.

De Guevara, J.F., Maudos, J. and Pérez, F. (2005) Market power in European banking sectors, Journal of Financial Services Research, 27(2), 109-37.

De Waal, A., Duong, H. and Ton, V. (2009) High performance in Vietnam: the case of the Vietnamese banking industry, Journal of Transnational Management, 14(3), 179-201.

Demirguc-Kunt, A. and Martínez Pería, M.S. (2010) A framework for analyzing competition in the banking sector: An application to the case of Jordan, The World Bank.

Ehrmann, M., Gambacorta, L., Martinez-Pagés, J., Sevestre, P. and Worms, A. (2003) The effects of monetary policy in the euro area, Oxford Review of Economic Policy, 19(1), 5872.

Ferri, G., Kalmi, P. and Kerola, E. (2014) Does bank ownership affect lending behavior? Evidence from the Euro area, Journal of Banking \& Finance, 48, 194-209.

Fungáčová, Z., Nuutilainen, R. and Weill, L. (2016) Reserve requirements and the bank lending channel in China, Journal of Macroeconomics, 50, 37-50.

Gambacorta, L. (2005) Inside the bank lending channel, European Economic Review, 49(7), 1737-59.

Gunji, H. and Yuan, Y. (2010) Bank profitability and the bank lending channel: Evidence from China, Journal of Asian Economics, 21(2), 129-41.

Hoshi, T., Scharfstein, D.S. and Singleton, K.J. (1993) Japanese corporate investment and Bank of Japan guidance of commercial bank lending, Japanese Monetary Policy, University of Chicago Press, 63-94.

Huynh, T.L.D., Nasir, M.A., Nguyen, S.P. and Duong, D. (2020) An assessment of contagion risks in the banking system using non-parametric and Copula approaches, Economic Analysis and Policy, 65, 105-16.

Kashyap, A.K. and Stein, J.C. (1994) The impact of monetary policy on bank balance sheets, 0898-2937, National Bureau of Economic Research.

Kashyap, A.K., Stein, J.C. and Wilcox, D.W. (1992) Monetary policy and credit conditions: Evidence from the composition of external finance, 0898-2937, National Bureau of Economic Research.

Micco, A. and Panizza, U. (2006) Bank ownership and lending behavior, Economics Letters, 93(2), 248-54.

Ngo, T.T., Le, M.Q. and Ngo, T.P. (2019) Incorporating risk into technical efficiency for Vietnam's and ASEAN banks, Journal of Asian Business and Economic Studies.

Oliner, S.D. and Rudebusch, G.D. (1993) Is there a bank credit channel for monetary policy?, Board of Governors of the Federal Reserve System (US).

Olivero, M.P., Li, Y. and Jeon, B.N. (2011a) Competition in banking and the lending channel: Evidence from bank-level data in Asia and Latin America, Journal of Banking \& Finance, 35(3), 560-71. 
Olivero, M.P., Li, Y. and Jeon, B.N. (2011b) Consolidation in banking and the lending channel of monetary transmission: Evidence from Asia and Latin America, Journal of International Money and Finance, 30(6), 1034-54.

Perera, A., Ralston, D. and Wickramanayake, J. (2014) Impact of off-balance sheet banking on the bank lending channel of monetary transmission: Evidence from South Asia, Journal of International Financial Markets, Institutions and Money, 29, 195-216.

Pham, V.A. (2019) Impacts of the monetary policy on the exchange rate: case study of Vietnam, Journal of Asian Business and Economic Studies.

Rhoades, S.A. (1993) The herfindahl-hirschman index, Fed. Res. Bull., 79, 188.

Sapienza, P. (2004) The effects of government ownership on bank lending, Journal of Financial Economics, 72(2), 357-84.

Vo, X.V. and Nguyen, H.H. (2018) Bank restructuring and bank efficiency-The case of Vietnam, Cogent Economics \& Finance, 6(1), 1520423. 